\title{
Effect of Spiritual Intelligence and Asta Brata Leadership to the Culture of Tri Hita Karana and Employment Performance
}

\author{
Ida Bagus Agung Dharmanegara ${ }^{1}$, Made Sudarma ${ }^{2}$, Noermijati ${ }^{2}$, And Solimun ${ }^{2}$ \\ (Study in Rural Credit Institutions in Badung regency of Bali Province) \\ ${ }^{1}$ Doctorate Candidate, Faculty of Economic and Business, University of Brawijaya, Malang, Indonesia \\ ${ }^{2}$ Faculty of Economic and Business, University of Brawijaya, Malang, Indonesia
}

\begin{abstract}
Human resources (HR) that talented employees are the foundation of an organization in a competitive advantage. A strong foundation for an organization to improve performance is the main one of which comes from the quality of Employment Performance. Basically Human Resources (HR) refers to people in the organization. Without effective people, it seems impossible for the organization to achieve its objectives. Human resources to make the resources with other organizations to run optimally. Quality employees working in an organization can be influenced by the cultures that are in the organization. Organizational culture is a reflection of the behavior of the employees from the application of values prevailing in the organization. Quality performance can likewise sourced from spiritual intelligence and leadership qualities of being a model of supervision that worked by employees. In this study, used the organizational culture Culture and Leadership Tri Hita Karana Astra Brata as variables tested to determine its effect on Employment Performance through Cultural Tri Hita Karana in Badung Regency Village Credit Institutions of Bali. Results showed that that the Spiritual Intelligence and Astra Brata Leadership have an influence on the culture of Tri Hita Karana, but the The Culture of Tri Hita Karana can not be mediating the effect of Spiritual Intelligence and Astra Brata Leadership. Astra Brata proven leadership directly affects the performance displayed by employees at Village Credit Institutions of Bali Badung regency. Total $R^{2}$ value of $88.4 \%$ indicates that the diversity of data that can be explained by the model is equal to $88.4 \%$. While the remaining $11.6 \%$ is explained by other variables (which is not contained in the model) and error.
\end{abstract}

Keywords: Spiritual Intelligence, Astra Brata Leadership, The Culture of Tri Hita Karana, and Employment Performance.

\section{Background}

For many organizations, talented employees are the foundation of competitive advantage. If it was engaged in competition based on new ideas, customer service is excellent, or fast, decisions - decisions that are accurate, it is important to have employees - employees who are very good. Of course not every organization not only compete with the best employee ownership basis, but for organizations that do not do so, the employee is the primary source of performance (Mathis and John, 2006). The most important assets of an organization that should be owned by the company and is considered by management is the human assets of the organization. HR basically refers to people in the organization. Without effective people, it seems impossible for the organization to achieve its objectives. Human resources to make the resources with other organizations to run optimally.

The role of human resource managers is very important in order to create a highly skilled workforce and have high knowledge in order to achieve the expected performance. High Employment Performance is expected to contribute significantly to the performance and progress of the company, because the company's performance is a synergy of all employees and the performance of the whole team / unit - its business units. The performance of the employees will reflect the level of performance that can be achieved by the organization as a whole (Maryani, 2010).

In this regard, one of the aspects that need to be considered for improvement, coaching is a continuous quality improvement organization management. Good management means how to manage a job in order to achieve results that match the specified purpose, it requires special technical skills, not just technical expertise, but also expertise in leading people or subordinates or employees (Herujito, 2004). The leader's job is to motivate workers and improve working methods to ensure that the employee can perform the task optimally, without experiencing a variety of disorders that can affect performance. Man is a being planners, perpetrators, and the determinant of an organization's operations. Therefore any sophisticated tools that the organization will not have utility, if the active role of human resources is not included. Relies on the quality of human resources organizational performance can certainly be improved. As disclosed Day and Lord (in Robbins, 2006) is no doubt that the success of an organization, or any group within an organization is dependent on the quality of leadership. Successful leader is able to anticipate changes and take advantage of opportunities mightily, 
motivate followers to achieve high levels of productivity, correct poor performance, and encourage organizations towards the goal.

Bass (1995) distinguished leadership over the transactional and transformational leadership. Transactional leadership is the achievement of organizational goals through social exchange (for example the concept of reward and punishment), whereas transformational leadership to convince the others to look at things differently than others, and respond positively to an alternative vision of the leader. Transformational leadership with charismatic leadership. The essence of transformational leadership is the willingness and ability of leaders to raise awareness of other people by making use of moral values and strong ideals.

Transformational leadership can be learned, and should be the subject of training and management development. Research has shown that leaders at all levels can be trained to be charismatic (Bass, 1990). Astra Brata leadership is a form of leadership which consists of eight leadership traits, among others: 1). Indrabrata the leadership traits that give priority to the welfare of its people, 2). Yamabrata, leadership traits that fair to the people, 3). Suryabrata the leadership qualities that are always trying to improve service to the people of responsibility, 4). Candrabrata the authoritative nature of the leader, 5). Bayubrata, the nature of the interests of the people's leader, 6). Kuwera, the nature of leadership that promotes prosperity, 7). Warunabrata, the nature of the leader who is able to eradicate pain and illness in the community, and 8). Agnibrata, the nature of the leadership role as community organizer.

The success of a leader is influenced by a variety of intelligence among others, intellectual quotion (IQ), emotional quotion (EQ), quotion spiritual (SQ), and adversity quotient (AQ). Balance the use of the intellect fourth in the work is not only successful but also make someone happy (Gina, 2007).

Zohar and Marshall (2007) that a leader is required to act on high motivation, which includes spiritual transformation. With spiritual intelligence is good then a leader will be able to run the model with good leadership as well. Leadership role in improving the performance of employees can not be separated from the culture of the organization (organizational culture). As in the theory of path goal theory of leadership contingency model of Robert House states that the leader's job is to help their followers or subordinates to achieve their goals and satisfaction with performance that is mediated by the environment (culture), the structure of assignments, experiences and perceptions of subordinates. This theory also explains that the performance and employee satisfaction is positively affected when leaders compensate for things - things that are lacking in themselves employees or work situations. The role of leaders influence the behavior of subordinates so that any progress in the organization (Robbins, 2006).

Robbins (2006) states that organizational culture is a common perception held by members - members of the organization and become a system of shared meaning, while Schein (2004) states that organizational culture is a pattern that contains the basic assumptions are realized and studied by members of the group in relation to organizational problem solving. Hofstede (1980) further define organizational culture as a pattern of thoughts, feelings and actions of a social group that distinguishes with other social groups. Susanto (2008) states that an organization's culture is not only understood the value of the system alone but also used as a handle human resources in performing its obligations and behavior in organizations.

The research was conducted in Badung Regency Village Credit Institutions of Bali Province practically apply the values in the culture of Tri Hita Karana in service ethics associated with his work ethic. Work ethic to the Hindu culture embodied in the Tri Hita Karana Bali as pawongan aspect, where there is the foundation of the spirit of sacrifice (yadnya) and viewed the work as God commands. By itself imply that a man is not justified to work abroad - random (Gorda, 1996). Village Credit Institutions managers love the philosophy of the organization is the implementation of the Bali culture Palemahan aspects. Palemahan aspects implied in the value of environmental sustainability that should be guarded by every member of the organization. Thus there is an indication that reflect the implementation of Tri Hita Karana Bali LPD in the integrity of the implementation parahyangan. Work ethic as pawongan implementation and environmental sustainability as palemahan implementation. Management phenomenon that emphasizes honesty, ethics and environmental sustainability reflects the implementation of value - value kurtur Tri Hita Karana Bali.

Griffin (1987) states that performance is one of the total collection of work that is in its own workers. Meanwhile, according to Mangkunagara (2001) the term is derived from the performance of job performance or actual performance (actual performance achieved one). So the notion of performance is the result of the quality and quantity of work that achieved an employee in carrying out their duties in accordance with the responsibilities assigned to him. Performance measurement according to Mathis and Jackson (2006) based on the five elements, among others, the quantity of work, quality of work, timeliness of work, attendance, and ability to cooperate.

Several empirical studies have described an important role in improving the performance of the organization's culture. Gede (2010) in his research shows that the culture of the organization Tri Hita Karana tepatya culture is an integral part of the process of adaptation is very useful as a determinant of organizational performance and effectiveness of the organization. Research Gunawan (2009) suggests that leadership style 
affects the performance, organizational culture affect performance, job satisfaction affects the performance, work motivation affect the performance of the organization, work motivation effect on leadership, organizational culture affect the leadership style and organizational culture affect the performance .

Based on these considerations, this study uses the value - THK cultural values in the practice of organizational culture. Some results of this study are not consistent, a research gap (research gap) is attractive to be revealed.

\section{Materials And Methods}

Target population in this study were all Village Credit Institutions (LPD) in the Province of Bali. Village Credit Institutions is a business entity owned by a savings and loan that has a traditional village primary function and purpose of the community to raise funds and distribute in the form of loans for activities that are productive as the development and preservation of the values of local wisdom (Article 7 Regulation No. 8 of 2002 on Credit Institutions Village Business field).

Given that the target population in real terms can not be met, then the population of this study, namely access throughout the Village Credit Institutions (LPD) Badung regency which spread into 6 areas of work include Mengwi, North Kuta, Kuta, South Kuta, Abiansal and evening with a total of Institutions Village Credit as much as 122 . The samples in this study took the entire population access to as many as 122 Village Credit Institutions represented by 122 employees.

Partial Least Square (PLS) was first developed by Herman Wold, he is the teacher of Karl Joreskog (who developed SEM). This model was developed as an alternative to a situation where theory is weak and or indicators available do not meet the measurement model reflesif. Wold says PLS as "soft modeling". PLS is a powerful method of analysis because it can be applied at all scales of the data, does not require a lot of assumptions and sample size should not be big. PLS than can be used as a confirmation of the theory can also be used to build a relationship that does not exist or terorinya basis for testing propositions (Solimun, 2010).

PLS approach is based on the analysis of the shift measurement model parameter estimation research on the measurement of relevant predictions. So the focus should shift from simply measuring valuation parameter estimation significance (structural paths and factor loading) into predictive validity. Basic parameters of significance testing is resampling (repeated sampling) developed by Geisser (1975) and Stone (1974) with sample predictive technique, namely the synthesis of cross-validation (cross-validation) and suitability function perspective: observations (observable) or potential observations ( potential observable) is much more relevant than an artificial construct parameter estimates (Chin, 1998). PLS primarily aim to construct the estimated variance of endogenous variables along with its manifestation, termed reflexive indicators (reflective indicators), the other is an indicator construct specificity can also be formed in the form of formative, termed the formative indicators (formative indicators).

Compared with the SEM approach that has been widely used (by applying LISREL and AMOS software), PLS is able to avoid two serious problems, namely:

(a) Solutions are not acceptable (inadmissible solution): this happens because the PLS-based variance and covariance is not, so the problem of matrix singularity will never happen. In addition, work on the PLS structural model are recursive, so the problem un-identified, under-identified or over-identified also not going to happen.

(b) Factors that can not be determined (factor indeterminacy), which is a more than a factor contained in a set of indicator variables. Specific indicators are formative not require any comon factor that will always be obtained latent variables that are composites. In this case the latent variable is a linear combination of the indicators.

Testing measures based PLS models with empirical research SmartPLS software (Solimun and Rinaldo, 2009, Chin, 1998) are as follows:

\section{1. specifications Model}

Relationship between variables path analysis consists of:

a) Outer models, the specification of the relationship between latent variables with the indicator, also called the outer relation or measurement models, define the characteristics of the variable constructs its manifestation. Reflexive indicator models can be written as the following equation:

$$
\begin{aligned}
& \mathrm{x}=\Lambda_{\mathrm{x}} \xi+\varepsilon_{\mathrm{x}} \\
& \mathrm{y}=\Lambda_{\mathrm{y}} \eta+\varepsilon_{\mathrm{y}}
\end{aligned}
$$

Where $\mathrm{x}$ and $\mathrm{y}$ are the indicators for the latent exogenous variables $(\xi)$ and endogenous $(\eta)$. While $\Lambda_{\mathrm{x}}$ and $\Lambda_{\mathrm{y}}$ is the loading matrix that describes such a simple regression coefficients linking the latent variable to the indicator. Residual measured by $\varepsilon_{\mathrm{x}}$ and $\varepsilon_{\mathrm{y}}$ can be interpreted as a measurement error or noise

Formative indicator model equation can be written as follows: 


$$
\begin{aligned}
& \xi=\Pi_{\xi} x+\delta_{x} \\
& \eta=\Pi_{y} y+\delta_{y}
\end{aligned}
$$

Where $\xi, \eta$, $x$, and y equal to the previous equation. Пx and Пy are such as multiple regression coefficient from the latent variable to the indicator, whereas $\delta_{\mathrm{x}}$ and $\delta_{\mathrm{y}}$ are the residuals of the regression.

Model specification and analysis of this research line is:

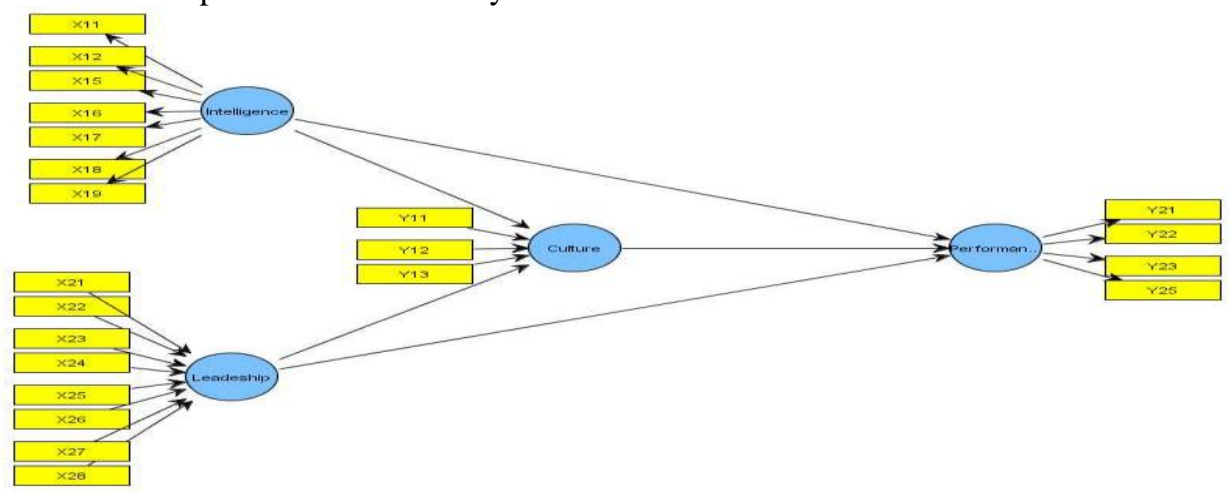

Figure 1. Interpersonal Model Research Variables

Inner model (structural model), the specification of the relationship between latent variables (structural model). In the PLS model of Figure 1 above, inner models obtained are as follows:

$$
\begin{aligned}
& \mathrm{Y} 1=\gamma_{1} \mathrm{X} 1+\gamma_{2} \mathrm{X} 2+\zeta_{1} \\
& \mathrm{Y} 2=\beta_{1} \mathrm{Y} 1+\gamma_{2} \mathrm{X} 1+\gamma_{3} \mathrm{X} 2+\zeta_{2}
\end{aligned}
$$

\section{Struktural Model}

Testing hypothesis $(\beta, \gamma$, and $\lambda)$ conducted by Bootstrap resampling method developed by Geisser (1975) and Stone (1974). Statistical test used is the t-statistic or $t$ test. Thus the assumption of distributed data free (free distribution), does not require the assumption of a normal distribution, and does not require a large sample (recommended minimum of 30 samples).

However, the PLS model is assumed to have a linear relationship. The method used is the Curve Fit with the principle of parsimony, which is said to be a linear relationship if the linear model is significant ( $p$ value $<0.05)$, or if the entire model may be non-significant $(p>0,05)$.

\section{Direct effect and Mediation Variables}

As Figure 1, note that there is a direct effect of the five models in this study, among other things:

a. Relationship between Spiritual Intelligence to The Culture Tri Hita Karana with the following constructs,

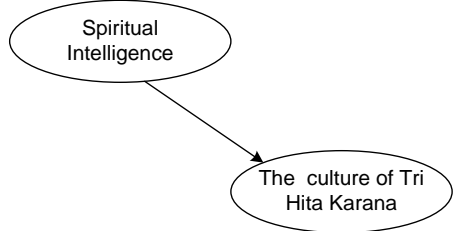

b. Relationship between Astra Brata Leadership to The Culture of Tri Hita Karana

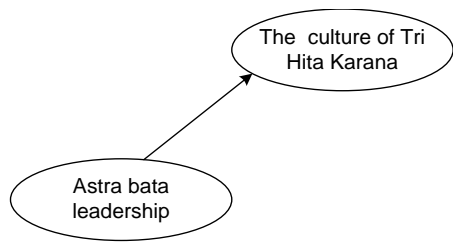

c. Relationship between Spiritual Intelligence to Employment Performance 


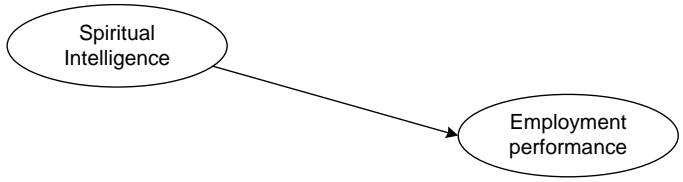

d. The relationship between Astra Brata Leadership to Employment Performance

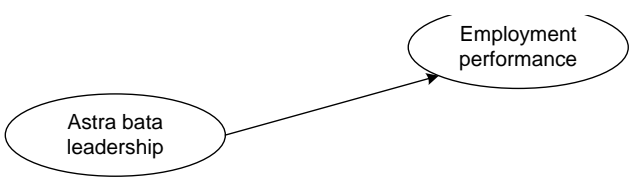

e. The relationship between The culture of Tri Hita Karana to Employment Performance

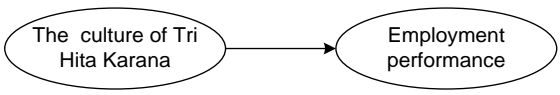

As for the influence of mediating variables in this study consists of two structural models, as follows,

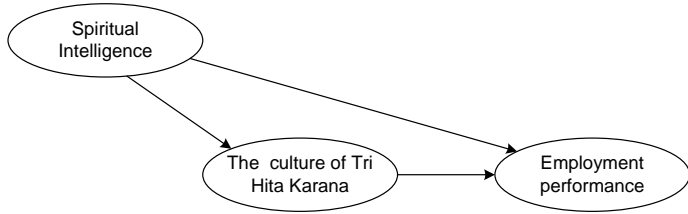

(a) The Culture of Tri Hita Karana Mediation Effect of Spiritual Intelligence in the Employment Performance

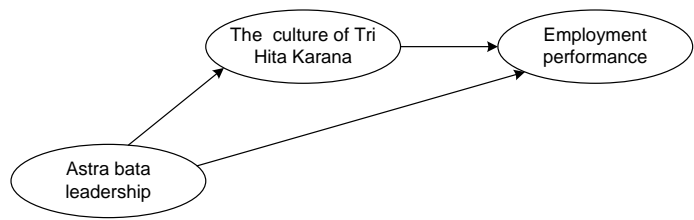

(b) The Culture of Tri Hita Karana Mediation on Astra Brata Leadership Influence Astrabata the Employment Performance.

\subsection{Testing Goodness of Fit Model}

\section{Results}

Goodness of Fit Testing on the inner structural model using the model-predictive value relevance (Q2). $\mathrm{R} 2$ values of each endogenous variable in this study are as follows: 1) for the variable $\mathrm{Y} 1$ obtained R2 of 0.703 ; 2) for variable Y2 obtained R2 of 0.608 .

Predictive value-relevance is obtained by the formula:

$\mathrm{Q}^{2}=1-\left(1-\mathrm{R}_{1}^{2}\right)\left(1-\mathrm{R}_{2}{ }^{2}\right) \ldots\left(1-\mathrm{R}_{\mathrm{p}}{ }^{2}\right)$

$\mathrm{Q}^{2}=1-(1-0,703)(1-0,608)=0,884$

$\mathrm{H}$ acyl calculations showed predictive value-relevance of 0.884 or $88.4 \%$. Relevance predictive value of $88.4 \%$ also indicated that the diversity of data that can be explained by the model is equal to $88.4 \%$ or in other words, the information contained in the data is $88.4 \%$ can be explained by the model. While the remaining $11.6 \%$ is explained by other variables (which is not contained in the model) and error. From the above phenomenon is said to have a decent model of the relevant predictive value.

\subsection{Testing linearity assumption}

In the PLS analysis, there is an assumption that must be met before the analysis is the assumption of linearity, which requires the relationship between variables is linear. Assumption of linearity using the Curve Fit is a linear relationship between variables declared if one of the two following possibilities: (1) a significant linear model (linear model sig> 0.05), (2) non-significant linear models and all models may also nonsignificant (sig linear models $>0: 05$, and sig models than linear> 0:05). The test results in the appendix shows the value of the linear model is $>0.05$ so that the model is said to meet the assumption of linear and defined. 


\subsection{Outer Model Testing Results}

Factor loading value indicates the weight of each indicator as a measure of each latent variable. Indicator with the largest factor loading indicates that the indicator variable as a measure of the strongest (dominant). Are presented in Table 1 (details in Appendix).

Based on the table it can be seen that,

1. Spiritual Intelligence employees on variable (X1), the seven indicators: Ability to be flexible (X1.1), Higher Consciousness Levels (x1.2), Quality of life based on the vision and mission (x1.5), reluctance to cause harm (X1.6), holistic-minded (x1.7), Asking to seek fundamental answers (X1.8), and full devotion and responsibility (X1.9). Of outer value that obtained the highest loading indicator holistic-minded (x1.7) form the most dominant variable Spiritual Intelligence employees.

Table 1. Loading on the Outer value of Each Variable

\begin{tabular}{|c|c|c|c|c|c|c|c|c|}
\hline Indicator & \multicolumn{2}{|c|}{ X1 } & \multicolumn{2}{|c|}{ X2 } & \multicolumn{2}{|c|}{ Y1 } & \multicolumn{2}{|c|}{ Y2 } \\
\hline 1 & X1.1 & $0.664 *$ & X2.1 & $0.175^{*}$ & Y1.1 & $0.565^{*}$ & Y2.1 & $0.625 *$ \\
\hline 2 & $\mathrm{X} 1.2$ & $0.764 *$ & $\mathbf{X 2 . 2}$ & $0.206^{*}$ & Y1.2 & $0.474^{*}$ & Y2.2 & $0.814 *$ \\
\hline 3 & $\mathbf{X 1 . 3}$ & $0.694 *$ & $\mathrm{X} 2.3$ & $0.241 *$ & Y1.3 & $0.202^{*}$ & Y2.3 & $0.805^{*}$ \\
\hline 4 & $\mathrm{X1.4}$ & $0.525 *$ & X2.4 & $0.295^{*}$ & & & Y2.5 & $0.461 *$ \\
\hline 5 & $\mathrm{X} 1.5$ & $0.463 *$ & $\mathrm{X} 2.5$ & $0.152 *$ & & & & \\
\hline 6 & X1.6 & $0.701 *$ & $\mathrm{X2.6}$ & $0.062 *$ & & & & \\
\hline 7 & $\mathbf{X 1 . 7}$ & $0.791 *$ & $\mathbf{X} 2.7$ & $0.151^{*}$ & & & & \\
\hline 8 & & & X2.8 & $0.001 *$ & & & & \\
\hline
\end{tabular}

Specification: * sign stating that the weight significantly (p-value $<0.05)$

2. On Astra brata Leadership variable (X2) has eight leadership traits for the welfare of society (Sidhartha, 2009), where in this study to be an indicator that Indrabrata (X2.1) about the welfare of the community, Yamabrata (X2.2) about justice, Suryabrata (X2.3) of responsibility and dedication to all the people who led, candrabrata (X2.4) of the leaders of the serene face, Bayubrata (X2.5) about the interests of the people, Kuwerabrata (X2.6) about prosperity, Warunabrata (X2.7) about a leader who is able to eradicate the sufferings and ills of society, and Agnibrata (X2.8) people mover in the success of the program of work for the future of its people. Of outer value that obtained the highest weight indicator Astrabata Normative Leadership (X2.3) form the most dominant variable Astrabata Leadership, which Suryabrata indicator of the nature of a leader who has a sense of responsibility and dedication to all the people he leads.

3. At The Culture of Tri Hita Karana variables Work (Y1), the third indicator is parahyangan (Y1.1) regarding organizational culture on public relations to God, Pawongan (Y1.2) the organizational culture of human relations, and attenuation (Y1.3) the organizational culture of the relationship with the natural environment. Of outer value that obtained the highest weight indicator Parahyangan (Y1.1) form the most dominant variable The Culture of Tri Hita Karana Works. Thus the organizational culture at Village Credit Institutions predominantly shaped by the relationship between employees with God.

4. On Employment Performance variable (Y2), four indicators ie Quantity (Y2.1) Quality (Y2.2), timeliness (Y2.3), and the ability Cooperation (Y2.5). Of outer value that obtained the highest loading indicator Quality (Y2.2) form the most dominant variable Employment Performance.

\subsection{PLS Direct Effect and Mediation}

There are five direct relationships shaped effect or which has a direct bearing and influence shaped the two relations mediation, using PLS analysis results are summarized as Table 2,

Table 2.

Path Coefficient Test Results Direct and Indirect Effect of Spiritual Intelligence and Astra Brata Leadership to the Employment Performance Through The Culture Tri Hita Karana

\begin{tabular}{|c|c|c|}
\hline Relation & Coeffisient & P-value \\
\hline Spiritual Intelligence -> THK culture & 0.397 & 0.000 \\
\hline Astra Brata Leadership -> THK culture & 0.487 & 0.000 \\
\hline $\begin{array}{c}\text { Spiritual Intelligence -> Employment } \\
\text { Performance }\end{array}$ & 0.135 & 0.077 \\
\hline $\begin{array}{c}\text { Astra Brata Leadership -> Employment } \\
\text { Performance }\end{array}$ & 0.549 & 0.000 \\
\hline THK culture -> Employment Performance & 0.138 & 0.260 \\
\hline
\end{tabular}

Source: Data processed 2013 (Appendix 1)

Testing the direct influence of Spiritual Intelligence employees (X1) of the Cultural Tri Hita Karana (Y1) obtained a relationship coefficient of 0.397 with a value of $p$ (p-value) of 0.000 . Because the p-value (p-value) is smaller than the standard error $(\alpha)$ used in this study is 0.05 . This indicates a significant difference between spiritual intelligence (X1) to the culture of Tri Hita Karana (Y1). Coefficient of relationship between the two 
variables is positive indicates that the higher the value of spiritual intelligence (X1) will result in perceived higher the values prevailing in the culture of the organization as Tri Hita Karana (Y1).

The direct effect between Astra Brata Leadership (X2) on Cultural Tri Hita Karana (Y1) showed a coefficient of 0.487 and p-value (p-value) of 0.000 . P-value (p-value) is less than the standard error of 0.05 indicates a significant difference between Astra Brata Leadership (X2) on Cultural Tri Hita Karana (Y1). Judging from the sign of the relationship between the two variables is positive indicates that the higher the employees' perceptions of Astra Brata Leadership (X2) will improve the application of cultural values Tri Hita Karana prevailing in Badung Regency Village Credit Institutions of Bali.

Testing the direct influence of Spiritual Intelligence (X1) of the Employment Performance (Y2) in the Village Credit Institutions coefficient indicates a positive relationship with a p-value of 0.135 (p-value) 0.077 . $\mathrm{P}$-value ( $\mathrm{p}$-value) that exceeds the standard error of 0.05 indicates that there is no significant effect between Spiritual Intelligence (X1) of the Employment Performance (Y2). This means that the higher spiritual intelligence (X1) employees in Badung Regency Village Credit Institutions of Bali did not impact directly on the performance of the display.

Astra Brata Leadership (X2) affect Employment Performance (Y2) significantly indicated by the positive correlation coefficient of 0.549 with a p-value (p-value) of 0.000 which is smaller than 0.05 standard errors. Coefficient indicates a positive relationship that the higher the value of Astra Brata Leadership (X2) then it will have an effect on the performance displayed by employees at Village Credit Institutions of Bali Badung regency.

Direct effect coefficient between Cultures Tri Hita Karana (Y1) of the Employment Performance (Y2) with a p-value of 0.138 (p-value) of 0.260 which exceeds the standard error of 0.05 proved that the culture of Tri Hita Karana (Y1) proved to be no significant effect on Employment Performance (Y2). Thus note that the performance shown by employees in Badung Regency Village Credit Institutions of Bali was not affected by the increase in the values of culture Tri Hita Karana (Y1) contained in the organization.

Based on the results that have direct influence on the above mentioned, it can be concluded that the Employment Performance (Y2) are not directly affected by the Spiritual Intelligence (X1) and Cultural Tri Hita Karana (Y1) but influenced by the Astra Brata Leadership (X2).

Testing the mediating effect of The Culture of Tri Hita Karana (Y1) on Spiritual Intelligence influence employees (X1) of the Employment Performance (Y2) obtained indirect path coefficient between employees Spiritual Intelligence (X1) of the The Culture of Tri Hita Karana Work (Y1), and Cultural Tri Hita Work Karana (Y1) of the Employment Performance (Y2) respectively for 0397 and 0138 so that the inner value of the mediating effect of weight $0.397 \times 0.138=0.055$, with a $\mathrm{p}$-value (p-value) two consecutive ties of 0000 and 0.260 . Because the p-value (p-value) over 1 smaller effect than 0.05 but the influence of 2 larger than 0.05 , indicating a significant difference between the employee Spiritual Intelligence (X1) of the Cultural Tri Hita Karana (Y1), but not so on the relationship between culture Tri Hita Karana (Y1) of the Employment Performance (Y2). Thus, it can be concluded that the The Culture of Tri Hita Karana Work (Y1) is a variable that can not mediate the influence Spiritual Intelligence employees (X1) of the Employment Performance (Y2). Given the coefficient is positive, indicating the higher value of employee Spiritual Intelligence (X1), the Cultural mediation Tri Hita Karana (Y1) is the higher, can not result in an increase in performance displayed by the Employee (Y2).

Cultural mediation effects of Tri Hita Karana (Y1) on the influence Astra Brata Leadership (X2) of the Employment Performance (Y2) obtained indirect path coefficient between Astra Brata Leadership (X2) of the The Culture of Tri Hita Karana Work (Y1) and the Cultural Work of Tri Hita Karana ( Y1) of the Employment Performance (Y2) respectively for 0.487 and 0.138 so that the inner value of the mediating effect of weight $0.487 \times 0.138=0.067$, with a p-value (p-value) two consecutive ties for 0.000 and 0.260 . Because the p-value (pvalue) over 1 smaller effect than 0.05 but the influence of 2 larger than 0.05 , indicating a significant difference between Astra Brata Leadership (X2) on Cultural Tri Hita Karana (Y1), but not so on the relationship between culture Tri Hita Karana (Y1) of the Employment Performance (Y2). Thus, it can be concluded that the The Culture of Tri Hita Karana Work (Y1) is a variable that can not mediate the effect Astra Brata Leadership (X2) of the Employment Performance (Y2). Given the coefficient is positive, indicating the higher value Astra Brata Leadership (X2), the Cultural mediation Tri Hita Karana (Y1) is the higher, had no effect on the performance displayed by the employee (Y2).

\section{Conclusions And Recommendations}

Based on the above results, we can conclude some of the following:

1. The higher level of spiritual intelligence that employees, especially in terms of devotion and full responsibility for the duties, the employees are not encouraging in terms of improved performance.

2. The better the Astra Brata Leadership of a leader or chairman of Village Credit Institutions perceived by its employees, it can encourage employees to do their work well too. 
3. The better the employee spiritual intelligence does not mean the better the performance of the display through the implementation of the cultural values of Tri Hita Karana.

4. The better the Astra Brata Leadership a leader or chairman of Village Credit Institutions do not have an impact on improving Employment Performance through the implementation of the cultural values of Tri Hita Karana.

\section{References}

[1]. Bass, Bernard M. (1990). From Transactional to Transformational Leadership: Learning to Share the Vision. American Management Association New York : Organizational Dynamics, Winter 1990.

[2]. Chin, W.W. (1998) The partial least squares approach to structural equation modeling. In: Modern Methods for Business Research, Marcoulides, G.A. (ed.), pp. 295-336. Erlbaum Associates, London, UK.

[3]. Gede, Riana. (2010). The impact of the culture of Tri Hita Karana entrepreneurial orientation and market orientation as well as its consequences on business performance. PPSUB.

[4]. Geisser, S. (1975). The predictive sample reuse method with applications. Journal of the American Statistical Association, 70, 320-328.

[5]. Ginanjar, Agustian Ary (2007). Secrets of Success to Build Emotional and Spiritual Intelligence. Arga Publishing. Jakarta.

[6]. Gorda. I Gusti Ngurah. (1996). Hindu Ethics and Organizational Behavior. High school Satya Widya Dharma in collaboration with Kriya Gematama. Denpasar.

[7]. Griffin, R W. (1987). Toward an integrated theory of task design. Research in Organizational Behavior, 9, 79-120.

[8]. Gunawan, Ketut. (2009). Effect of Organizational Culture, Job Satisfaction And Motivation To Work Leadership Style And Organizational Performance. Dissertation. Graduate School of Economics. UB Malang.

[9]. Hair, J.F., Black, W.C., Babin, B.J., Anderson, R.E. 2010. Multivariate Data Analysis. ${ }^{\text {th }}$ Edition. New Jersey : Pearson Education Inc.

[10]. Herujito. M. Yayat (2004), Fundamentals of Management, Fourth Edition, Publisher PT Grasindo, Jakarta

[11]. Hofstede,G. (1980). Cultural consequences: International differences in work related values. Beverly Hills, CA: Sage.

[12]. Kenny, D. A, Ledermann, T., \& Macho, S. (2013). Assessing mediation in dyadic data using the Actor-Partner Interdependence Model. Structural Equation Modeling, 18, 595-612.

[13]. Mangkunegara, A.P. (2001). Human Resource Management Company. New Edition. Resdakarya teens. Bandung.

[14]. Maryani. (2010). Influence of Organizational Culture and leadership style and employee development to job satisfaction and performance of employees in retail establishments in South Sulawesi. Dissertation. Graduate School of Economics. UB Malang.

[15]. Mathis C Robert \& Jackson H John. (2006); Human Resources Management : Human Resource Management, Translation Diana Angelica, Publisher Salemba Four, Jakarta.

[16]. Robbins, Stephen. (2006). Organizational Behavior: Concepts, Controversies and Applications. Second Edition. Pudjaatmaka translation. Prenhallindo. Jakarta.

[17]. Schein. Edgar H. (2004). Organizational culture and leadership. John Wiley and Son.

[18]. Sidharta, Rai (2009). Asta Brata Hindu leadership and counsel Sri Rama other. Publisher Paramita. Surabaya.

[19]. Sobel, M. E. (1982). Asymptotic confidence intervals for indirect effects in structural equation models. In S. Leinhardt (Ed.), Sociological Methodology 1982 (pp. 290-312). Washington DC: American Sociological Association.

[20]. Solimun dan Rinaldo, A. (2009). PLS Structural Equation Modeling Approach and Application Software SmartPLS SEM and Amos. Statistics Laboratory, State University of Brawijaya.

[21]. Solimun. (2010). PLS Structural Equation Modeling Approach. Mathematics, University of Brawijaya.

[22]. Solimun (2013). Testing for Mediation Variable. What Necessary: International Conference of Basic Science. FMIPA of Brawijaya University.

[23]. Stone, M. (1974). Cross-validatory choice and the assessment of statistical predictions (with discussion). Journal of the Royal Statistical Society, B 36, 111-133.

[24]. Susanto, AB. (2008). Corporate culture and organizational culture. A strategy management approach. The Jakarta consulting group. Jakarta.

[25]. Zohar, Danah \& Marshall I. (2007). SQ : Spiritual Intelligence The Ultimate Intelligence. Interpreting Rahmani Astuti et al. Mizan Media Utama, Bandung. 